Article

\title{
The Effect of Renewable Energy Consumption on Sustainable Economic Development: Evidence from Emerging and Developing Economies
}

\author{
Mun Mun Ahmed ${ }^{1, *}$ and Koji Shimada ${ }^{2}$ \\ 1 Graduate School of Economics, Ritsumeikan University, 1-1-1 Noji-Higashi, Kusatsu, Shiga 525-8577, Japan \\ 2 Faculty of Economics, Ritsumeikan University, 1-1-1 Noji-Higashi, Kusatsu, Shiga 525-8577, Japan \\ * Correspondence: gr0332kk@ed.ritsumei.ac.jp
}

Received: 8 July 2019; Accepted: 26 July 2019; Published: 31 July 2019

check for updates

\begin{abstract}
The objective of the paper is to figure out the nexus between renewable energy consumption and sustainable economic development for emerging and developing countries. In this paper, a panel of 30 emerging and developing countries is selected using the World Development Indicators (WDI) of the World Bank, Renewable Energy Country Attractiveness Index (RECAI) by Ernst and Young, and a random selection method based on the current trend of renewable energy consumption for five different regions of the world i.e., Asia, South-Asia, Latin America, Africa and the Caribbean. To achieve the objective, robust panel econometric models such as the Pesaran cross-section dependence (CD) test, second generation panel unit root test, e.g., cross-sectional augmented IPS test (CIPS) proposed by Pesran (2007), panel co-integration test, fully modified ordinary least square (FMOLS) and dynamic ordinary least square (DOLS) are applied to check the cross-sectional dependence, heterogeneity and long-term relationship among variables. The panel is strongly balanced and the findings suggest a significant long-run relationship between renewable energy consumption and economic growth for selected South Asian, Asian and most of the African countries (Ghana, Tunisia, South Africa, Zimbabwe and Cameroon). But for the Latin American and the Caribbean countries, economic growth depends on non-renewable energy consumption. Renewable energy consumption in the selected countries of these two regions are still at the initial stage. In case of the renewable energy consumption and $\mathrm{CO}_{2}$ emissions nexus, for selected South Asian, Asian, Latin American and African countries both GDP and non-renewable energy consumption cause the increase of $\mathrm{CO}_{2}$ emissions. For the Caribbean countries only non-renewable energy consumption causes the increase of $\mathrm{CO}_{2}$ emissions. An important finding regarding renewable energy consumption-economic growth nexus indicates the existence of bi-directional causality. This supports the existence of a feedback hypothesis for the emerging and developing economies. In the case of renewable energy consumption- $\mathrm{CO}_{2}$ emissions nexus, there exists unidirectional causality. This supports the existence of the conservation hypothesis, where $\mathrm{CO}_{2}$ emissions necessitates the renewable energy consumptions. Based on the findings, the study proposes possible policy options. The countries, who have passed the take-off stage of renewable energy consumption, can take advanced policy initiatives e.g., feed-in tariff, renewable portfolio standard and green certificate for long-term economic development. Other countries can undertake subsidy, low interest loan and market development to facilitate the renewable energy investments.
\end{abstract}

Keywords: Renewable energy consumption; sustainable economic development; $\mathrm{CO}_{2}$ emissions

\section{Introduction}

Economic development is closely associated with the use of energy. At present, most of the countries of Asia, Latin America and Africa have developed their status from low-income to middle-income 
countries. With this shift in development pattern, the demand for energy is rapidly increasing in these countries. Energy use pattern in developing countries is mostly fossil fuel-based and the grid remote rural areas still lack required energy support. As a result, these countries are facing a two-fold energy challenge: providing basic energy services and ensuring energy sustainability.

In recent decades, worldwide attention towards Sustainable Development Goals (SDGs) and the geopolitical debate of limiting fossil fuel use have accelerated the importance of utilizing renewable energy as a viable option for inclusive and environment friendly economic growth.

According to the Chair of Renewable Energy Policy Network for the 21st Century (REN21), Arthouros Zervos, "in 2017, the contribution of renewable energy to global power generation was about 70\%, but global energy-related carbon dioxide emissions rose 1.4\%" (The Renewables 2018 Global Status Report, REN21 [1]). Rapid economic growth, cheaper fossil fuels and the absence of energy efficiency policies have fostered the carbon emissions. The report also points out that, at present, there is a worldwide revolutionary shift in the power sector towards a renewable energy future, but the rate of such shift is not as per the expectations. The salient finding in the report is, the positive change in the renewable energy investment pattern in some of the developing countries like, Rwanda, the Solomon Islands, the Marshall Islands and Guinea-Bissau. These countries are having renewable energy investments like most of the developed and emerging economies (p-15, REN21, 2018 report).

The uniqueness of this paper is its contribution to the body of knowledge regarding renewable energy and sustainable economic development for a panel of 30 countries from 5 different regions (Asia, South-Asia, Latin America, Africa and the Caribbean) of the world. Previous studies in this area are mostly on developed countries and some large developing countries like India, China, South Africa and Brazil etc., not on the panel of emerging and developing countries from diversified regions of the world economy. This study is important at the present era of 'sustainable development'. After adopting the Sustainable Development Goals (SDGs), most of the emerging and developing economies are now participating in the global transition to environment friendly, low-carbon energy system. For these countries, renewable energy investment is a timely decision. The objective of this paper is to determine the impact of renewable energy consumption on economic growth and $\mathrm{CO}_{2}$ emissions in the long run.

\section{Literature Review}

The existing theoretical and empirical literatures give different directions of causality (unidirectional, bi-directional and neutral) between energy consumption and economic growth. The growing concern about the negative impacts of fossil fuels on environment and the sustainability debate has necessitated carrying out present economic research on renewable energy and sustainable economic development.

There are four popular hypotheses (e.g., growth, conservation, feedback and neutrality hypothesis) in the energy consumption-economic growth nexus. According to the growth hypothesis, energy consumption is pivotal for economic growth and other inputs (e.g., technological improvement, capital and labour) cannot substitute the important role of energy in the production process. This implies that, any decrease in energy consumption may bring reduction in economic growth.

Conservation hypothesis postulates that economic growth determines the energy consumption of a country. This hypothesis completely differs from the growth hypothesis (e.g., energy consumption determines economic growth).

Feedback hypothesis asserts the existence of a bi-directional causal relationship between energy consumption and economic growth. As per this hypothesis, energy consumption and economic growth are interdependent.

Neutrality hypothesis postulates of no causality between energy consumption and economic growth. According to neoclassical economists, Stern and Cleveland (2004), energy does not influence economic growth [2]. This means that, capital and labour are the primary factors of production while energy is an intermediate input of production [3]. 
To summarize, growth and feedback hypotheses explain the long-term causality between energy consumption and economic growth, while conservation and neutrality hypotheses explain the short-term causality between them.

A brief presentation of previous studies and their findings on the above hypotheses is presented in Table 1.

Table 1. Previous Studies and Their Findings.

\begin{tabular}{|c|c|c|c|c|}
\hline Study & Method & Period & Countries & Findings \\
\hline \multicolumn{5}{|c|}{ Energy/Renewable Energy Consumption and Economic Growth Nexus } \\
\hline Kraft and Kraft (1978) [4] & Granger causality test & 1947-1974 & USA & $\begin{array}{l}\text { Gross Domestic Product (GDP) } \\
\text { determines energy consumption; } \\
\text { (Conservation hypo.) }\end{array}$ \\
\hline Soytas et al. (2001) [5] & Co-integration methodology & 1960-1995 & Turkey & $\begin{array}{l}\text { Energy consumption contributes to } \\
\text { GDP growth (Growth hypo.) }\end{array}$ \\
\hline Ewing et al. (2007) [6] & $\begin{array}{l}\text { Autoregressive Distributed } \\
\text { Lag (ARDL) model }\end{array}$ & 2001-2005 & USA & $\begin{array}{l}\text { GDP determines energy consumption } \\
\text { (Conservation hypothesis) }\end{array}$ \\
\hline Akinlo A.E. (2008) [7] & $\begin{array}{l}\text { Autoregressive Distributed } \\
\text { Lag (ARDL) model, Granger } \\
\text { causality test based on vector } \\
\text { error correction model } \\
\text { (VECM) }\end{array}$ & 1980-2003 & $\begin{array}{l}11 \text { Sub Saharan } \\
\text { African countries }\end{array}$ & $\begin{array}{c}\text { For Gambia, Ghana and Senegal, } \\
\text { there is bi-directional causality } \\
\text { between energy consumption and } \\
\text { economic growth. }\end{array}$ \\
\hline Cheng et al. (2009) [8] & Panel co-integration test & 1997-2007 & 30 OECD countries & $\begin{array}{l}\text { GDP determines energy consumption } \\
\text { (Conservation hypo.) }\end{array}$ \\
\hline Sadorosky P. (2009) [9] & $\begin{array}{l}\text { Fully Modified OLS (FMOLS) } \\
\text { for panel }\end{array}$ & 1994-2003 & $\begin{array}{l}18 \text { emerging } \\
\text { countries }\end{array}$ & $\begin{array}{l}\text { GDP determines renewable energy } \\
\text { consumption; (Conservation hypo.) }\end{array}$ \\
\hline Apergis and Payne (2010) [10] & Panel co-integration test & 1985-2005 & 20 OECD countries & $\begin{array}{l}\text { Bi-directional relationship between } \\
\text { GDP and energy consumption } \\
\text { (Feedback hypo.) }\end{array}$ \\
\hline Payne (2010) [11] & Granger causality test & 1949-2007 & USA & $\begin{array}{l}\text { Biomass energy consumption } \\
\text { contributes to GDP growth } \\
\text { (Growth hypo.) }\end{array}$ \\
\hline Apergis and Payne (2011) [12] & Panel co-integration test & 1980-2006 & $\begin{array}{l}6 \text { Central American } \\
\text { countries }\end{array}$ & $\begin{array}{l}\text { Energy consumption contributes to } \\
\text { GDP growth (Growth hypo.) }\end{array}$ \\
\hline Menegaki A.N. (2011) [13] & Random effect model & 1997-2007 & $\begin{array}{l}27 \text { European } \\
\text { countries }\end{array}$ & $\begin{array}{l}\text { Energy consumption and economic } \\
\text { growth are independent from each } \\
\text { other (Neutrality hypothesis) }\end{array}$ \\
\hline Fang Y. (2011) [14] & Ordinary least square (OLS) & 1978-2008 & China & $\begin{array}{l}\text { Renewable energy consumption } \\
\text { contributes to GDP growth } \\
\text { (Growth hypo.) }\end{array}$ \\
\hline Tiwari A.K. (2011) [15] & $\begin{array}{l}\text { Structural vector } \\
\text { autoregressive (VAR) analysis }\end{array}$ & 1960-2009 & India & $\begin{array}{l}\text { Renewable energy consumption } \\
\text { contributes to GDP growth } \\
\text { (Growth hypo.) }\end{array}$ \\
\hline Shahbaz M. et al. (2012) [16] & $\begin{array}{l}\text { Unit roots, Autoregressive } \\
\text { Distributed Lag (ARDL) } \\
\text { model and Granger causality }\end{array}$ & 1972-2011 & Pakistan & $\begin{array}{c}\text { In both long and short run, energy } \\
\text { consumption and economic growth } \\
\text { has bi-directional causality } \\
\text { (Feedback hypothesis). }\end{array}$ \\
\hline Bildirici (2014) [17] & $\begin{array}{l}\text { Fully Modified OLS (FMOLS) } \\
\text { for panel }\end{array}$ & 1990-2011 & $\begin{array}{l}\text { Transition } \\
\text { economies }\end{array}$ & $\begin{array}{c}\text { Biomass energy consumption } \\
\text { contributes to GDP growth (Growth } \\
\text { hypo.) }\end{array}$ \\
\hline $\begin{array}{l}\text { Bildirici and Ozaksoy } \\
\text { (2014) [18] }\end{array}$ & Granger causality test & 1980-2011 & $\begin{array}{l}\text { European } \\
\text { transition } \\
\text { economies }\end{array}$ & $\begin{array}{l}\text { GDP determines renewable energy } \\
\text { consumption; (Conservation hypo.) } \\
\text { for Slovenia and Slovakia; Renewable } \\
\text { energy consumption contributes to } \\
\text { GDP growth for Bulgaria and } \\
\text { Romania (Growth hypo.) }\end{array}$ \\
\hline $\begin{array}{c}\text { Caraiani Chirata et al. (2015) } \\
\text { [19] }\end{array}$ & $\begin{array}{l}\text { Engle and Granger causality } \\
\text { tests }\end{array}$ & 1980-2013 & $\begin{array}{l}5 \text { emerging } \\
\text { European countries }\end{array}$ & $\begin{array}{l}\text { GDP determines renewable energy } \\
\text { consumption for Hungary, Poland } \\
\text { and Turkey (Conservation hypo.); } \\
\text { Renewable energy consumption } \\
\text { contributes to GDP growth for } \\
\text { Romania (Growth hypo.) }\end{array}$ \\
\hline Bildirici and Ersin (2015) [20] & Causality test & 1970-2013 & $\begin{array}{l}\text { UK, Canada, } \\
\text { Germany, Austria, } \\
\text { Finland, France, } \\
\text { Italy, Mexico, } \\
\text { Portugal and } \\
\text { the USA }\end{array}$ & $\begin{array}{c}\text { In USA bi-directional relationship } \\
\text { between GDP and renewable energy } \\
\text { consumption (Feedback hypo.) and } \\
\text { for other countries, GDP determines } \\
\text { renewable energy consumption; } \\
\text { (Conservation hypo.) }\end{array}$ \\
\hline Bloch H. et al. (2015) [21] & $\begin{array}{l}\text { Autoregressive Distributed } \\
\text { Lag (ARDL) model and vector } \\
\text { error correction model } \\
\text { (VECM) }\end{array}$ & $\begin{array}{c}1969,1973,1997 \\
1998,2001 \\
2002,2003\end{array}$ & China & $\begin{array}{c}\text { Bi-directional causality between } \\
\text { renewable, non-renewable energy } \\
\text { consumption and economic growth } \\
\text { (Feedback hypo.) }\end{array}$ \\
\hline $\begin{array}{l}\text { Paramati R. Sudarshan et al. } \\
\text { (2017) [22] }\end{array}$ & $\begin{array}{l}\text { Panel unit root test, panel } \\
\text { co-integration and Fully } \\
\text { Modified OLS (FMOLS) }\end{array}$ & 1980-2012 & $\begin{array}{l}17 \text { countries of the } \\
\text { G20 }\end{array}$ & $\begin{array}{c}\text { Both renewable and non-renewable } \\
\text { energy consumption have significant } \\
\text { positive impact on economic output } \\
\text { and the impact of renewable energy } \\
\text { consumption on economic growth is } \\
\text { more than non-renewable } \\
\text { energy consumption. }\end{array}$ \\
\hline
\end{tabular}


Table 1. Cont.

\begin{tabular}{|c|c|c|c|c|}
\hline Study & Method & Period & Countries & Findings \\
\hline \multicolumn{5}{|c|}{ GDP, Energy Consumption and $\mathrm{CO}_{2}$ Emissions Nexus } \\
\hline Kaygusuz et al. (2007) [23] & $\begin{array}{l}\text { Analysis of reports of } \\
\text { European Commission and } \\
\text { European Energy Council }\end{array}$ & 2001-2004 & $\begin{array}{l}\text { EU-15 Member } \\
\text { States }\end{array}$ & $\begin{array}{l}\text { Wind energy plays significant role in } \\
\text { reducing } \mathrm{CO}_{2} \text { emissions. }\end{array}$ \\
\hline Sadorosky P. (2009) [9] & $\begin{array}{l}\text { Pedroni co-integration test } \\
\text { and Granger causality test }\end{array}$ & 1994-2003 & $\begin{array}{l}18 \text { emerging } \\
\text { countries }\end{array}$ & $\begin{array}{l}\text { In the long run there exists } \\
\text { conservation hypothesis, while in the } \\
\text { short run neutrality hypothesis } \\
\text { between energy consumption and } \\
\mathrm{CO}_{2} \text { emissions }\end{array}$ \\
\hline $\begin{array}{l}\text { Menyah and Wolde-Rufael } \\
\text { (2010) [24] }\end{array}$ & Granger causality test & 1960-2007 & USA & $\begin{array}{l}\text { Unidirectional causal flow from } \\
\text { economic growth to carbon emissions. }\end{array}$ \\
\hline Apergis (2010) [25] & Causal dynamics & 1984-2007 & $\begin{array}{l}19 \text { developing } \\
\text { countries }\end{array}$ & $\begin{array}{l}\text { Feedback hypothesis between } \\
\text { renewable energy consumption and } \\
\mathrm{CO}_{2} \text { emissions. }\end{array}$ \\
\hline Odhiambo (2012) [26] & Causal dynamics & 1970-1997 & South Africa & $\begin{array}{l}\text { Unidirectional causal flow from } \\
\text { economic growth to carbon emissions. }\end{array}$ \\
\hline Farhani S. (2013) [27] & Panel co-integration test & 1975-2008 & $\begin{array}{l}12 \text { Middle East and } \\
\text { North African } \\
\text { (MENA) countries }\end{array}$ & $\begin{array}{l}\text { In short term, growth hypothesis and } \\
\text { in long-term conservation hypothesis } \\
\text { between energy consumption and } \\
\mathrm{CO}_{2} \text { emissions. }\end{array}$ \\
\hline Omri A. (2013) [28] & Ordinary least square (OLS) & 1990-2011 & $\begin{array}{l}\text { Middle East and } \\
\text { North African } \\
\text { (MENA) countries }\end{array}$ & $\begin{array}{l}\text { GDP has positive and significant } \\
\text { impact, but financial development } \\
\text { and capital have negative impact on } \\
\mathrm{CO}_{2} \text { emissions. }\end{array}$ \\
\hline Zeb R. et al (2014) [29] & $\begin{array}{l}\text { Panel granger causality and } \\
\text { Fully Modified OLS (FMOLS) }\end{array}$ & 1975-2010 & $\begin{array}{l}\text { 5 SAARC countries } \\
\text { (Bangladesh, India, } \\
\text { Nepal, Pakistan, } \\
\text { and Sri Lanka) }\end{array}$ & $\begin{array}{l}\text { Granger causality results suggest } \\
\text { about neutrality hypothesis between } \\
\text { renewable electricity production and } \\
\qquad \mathrm{CO}_{2} \text { emissions. } \\
\text { The evidence of growth hypothesis } \\
\text { between them in FMOLS approach. }\end{array}$ \\
\hline Payne et al. (2014) [30] & $\begin{array}{l}\text { Panel co-integration and } \\
\text { vector error correction model } \\
\text { (VECM) }\end{array}$ & 1980-2011 & 25 OECD countries & $\begin{array}{c}\text { The evidence of feedback hypothesis } \\
\text { between renewable energy } \\
\text { consumption and } \mathrm{CO}_{2} \text { emissions. }\end{array}$ \\
\hline Mbarek, M.B (2014) [31] & $\begin{array}{l}\text { Autoregressive Distributed } \\
\text { Lag (ARDL) bounds testing } \\
\text { approach to co-integration and } \\
\text { error correction model (ECM) }\end{array}$ & 1980-2010 & Tunisia & $\begin{array}{l}\text { Unidirectional relationship between } \\
\text { GDP and } \mathrm{CO}_{2} \text { emissions in the } \\
\text { short run. }\end{array}$ \\
\hline Bouznit, M. et al. (2016) [32] & $\begin{array}{l}\text { Autoregressive Distributed } \\
\text { Lag (ARDL) model }\end{array}$ & 1970-2010 & Algiers & $\begin{array}{c}\text { A co-integration relationship between } \\
\mathrm{CO}_{2} \text { emissions, real GDP and } \\
\text { energy use. }\end{array}$ \\
\hline Mitic Petar et al. (2017) [33] & $\begin{array}{l}\text { Dynamic Ordinary Least } \\
\text { Squares (DOLS) and Fully } \\
\text { Modified OLS (FMOLS) }\end{array}$ & 1997-2014 & $\begin{array}{l}17 \text { transitional } \\
\text { economies }\end{array}$ & $\begin{array}{l}\text { Statistically significant long run } \\
\text { co-integrating relationship between } \\
\mathrm{CO}_{2} \text { emissions and GDP. }\end{array}$ \\
\hline
\end{tabular}

\section{Materials and Methods}

\subsection{Definition of Renewable Energy and Sustainable Development}

Renewable energy is defined by the U.S. Energy Information Administration (EIA) as, energy from naturally replenishing sources that are inexhaustible. The major types of renewable energy sources are biomass, solar energy, hydropower, wind energy and geothermal energy [34].

Sustainability covers an interconnected model of three pillars, e.g., economy, ecology and society. The term sustainable development is defined in the Brundtland Commission report, 'Our Common Future' in 1987, as "development that meets the needs of the present without compromising the ability of future generations to meet their own needs". Ensuring sustainable energy supply is one of the most important prerequisites of sustainable development [35].

Sustainable economic development is the economic development that is concerned with the improvement of the living standards of people by providing lasting and secured livelihood, minimizing resource depletion and environmental degradation [36]. It is a holistic approach of connecting economic growth with social and environmental development.

\subsection{Description of Variables and Countries in the Research}

In this paper, we will examine the effects of renewable energy consumption on economic growth and carbon dioxide $\left(\mathrm{CO}_{2}\right)$ emissions across the panel of 30 countries from five regions (South Asia, Asia, Latin America, Africa and the Caribbean). The data collected from different sources e.g., World Development Indicators (WDI), 2018 of the World Bank, World Energy Statistics and Balances, 2016 of 
the International Energy Agency and the International Labour Organization dataset 2018, International Monetary Fund (IMF) Investment and Capital Stock dataset, 2018. The dataset covers the period of 1994-2014, spanning 20 years. The variables in this study are: GDP, renewable energy consumption consisting energy from solar, hydro, wind, biogas and biofuels, non-renewable energy consumption consisting energy produced from coal, natural gas and oil, labour force participation, fixed capital and $\mathrm{CO}_{2}$ emissions. These variables are transformed into log-linear form, to avoid the problems associated with dynamic properties of the data series.

Countries are selected from five different regions of the world economy e.g., South Asia (India, Bangladesh, Pakistan, Sri-Lanka, Nepal, and Bhutan), Asia (China, South Korea, Malaysia, Philippines, Thailand, and Indonesia), Latin America (Colombia, Peru, Bolivia, Ecuador, and Costa Rica), Africa (Ghana, Kenya, Zimbabwe, Tunisia, Uganda, Nigeria, South Africa, Senegal, Cameroon, Chad, and Mozambique) and the Caribbean (Haiti and Jamaica). All these countries have their renewable investments in solar power, wind power, hydro power and biomass sectors.

International Renewable Energy Agency's (IRENA) report (2017) on global renewable energy capacity shows that, renewable energy capacity in whole Asia reached at $918 \mathrm{GW}$ in 2017. Biggest contribution in this field came from China and India. China is one of the major contributors in the worldwide growth of renewable power generating capacity. In 2017, China's solar capacity became 36 times more than it was in five years ago. In 2016, the production of electricity from solar power was 130 GW, which was more than the government's target for 2020. In 2016, India's renewable power generating capacity was $18 \%$. The capacity became $10 \%$ of the global growth in 2017. Since 2016, India's solar energy capacity started increasing. It was about 19 GW in 2016 [37].

According to the Renewables 2018 Global Status report, use of biogas for cooking shows a sharp increase in South-Central and South-East Asian countries. In the Latin American region, biofuel production grew 2\% in 2017 from the production of 2016. In spite of having positive prospects of growth, in Africa, production and use of biofuels is still at its primary stage (P-37, Renewables 2018 Global Status report REN21).

\subsection{Methodology}

This paper proposes to analyse two main issues. One is the impact of renewable energy consumption on economic output and another is the impact of renewable energy consumption on $\mathrm{CO}_{2}$ emissions for the selected countries. The study employs the Cobb-Douglas production [38] function to analyse the correlation between energy consumption and economic growth. Commonly the equation of the production function is as follows:

$$
\mathrm{Y}=\mathrm{C} \cdot \mathrm{R}^{\alpha 1} \cdot \mathrm{L}^{\alpha 2} \cdot \mathrm{K}^{\alpha 3} \cdot \mathrm{NR}^{\alpha 4}
$$

Here, Y denotes domestic output, R stands for renewable energy consumption, NR, L and K stand for non-renewable energy consumption, labour and capital respectively, $\mathrm{C}$ is a positive constant (the level of technology). $\alpha 1, \alpha 2, \alpha 3$ and $\alpha 4$ denote returns to scale associated with renewable energy consumption, labour, capital and non-renewable energy consumption respectively.

Two models are developed to analyse the relationship of renewable energy consumption with economic growth and $\mathrm{CO}_{2}$ emissions. The model-I is to analyse the impact of energy consumption on economic growth:

$$
\mathrm{Y}_{\mathrm{it}}=\mathrm{f}\left(\mathrm{REC}_{\mathrm{it}}, \mathrm{NREC}_{\mathrm{it}}, \mathrm{L}_{\mathrm{it}}, \mathrm{K}_{\mathrm{it}}\right)
$$

The subscripts $i$ and $t$ denote country and time period respectively. As a measure of economic output, we use GDP or Y constant 2010 US\$, gross fixed capital formation (K) constant 2010 US\$ and total number of labour force (L). We use both renewable and non-renewable energy consumption measured in terra joules. 
Equation (2) is parameterized as follows:

$$
\mathrm{Y}_{\mathrm{it}}=\alpha \cdot \mathrm{REC}_{\mathrm{it}}^{\beta 1} \cdot \mathrm{NREC}_{\mathrm{it}}^{\beta 2} \cdot \mathrm{L}_{\mathrm{it}}^{\beta 3} \cdot \mathrm{K}_{\mathrm{it}}^{\beta 4}
$$

The log transformation of Equation (3) is as follows,

$$
\log \mathrm{Y}_{\mathrm{it}}=\log \alpha+\beta 1 \cdot \log \mathrm{REC}_{\mathrm{it}}+\beta 2 \cdot \log \mathrm{NREC}_{\mathrm{it}}+\beta 3 \cdot \log \mathrm{L}_{\mathrm{it}}+\beta 4 \cdot \log \mathrm{K}_{\mathrm{it}}+\varepsilon_{\mathrm{it}}+\gamma_{\mathrm{i}}
$$

Here, $\log \alpha$ is constant and $\beta 1, \beta 2, \beta 3$ and $\beta 4$ are elasticities of output with respect to renewable energy consumption, non-renewable energy consumption, labour force and gross fixed capital formation respectively. $\varepsilon_{i t}$ is an error term and $\gamma_{\mathrm{i}}$ shows an individual effect.

Another issue related to the study is, the relationship between renewable energy consumption and $\mathrm{CO}_{2}$ emissions. For the empirical determination of the impact of GDP, renewable and non-renewable energy consumption on carbon dioxide $\left(\mathrm{CO}_{2}\right)$ emissions, the equation of model-II is as follows,

$$
\mathrm{CO}_{2 \mathrm{it}}=\mathrm{f}\left(\mathrm{Y}_{\mathrm{it}}, \mathrm{REC}_{\mathrm{it}}, \mathrm{NREC}_{\mathrm{it}}\right)
$$

The subscripts i and $t$ denote country and time period respectively. As economic output, we use GDP or (Y) constant 2010 US\$. REC and NREC represent renewable energy consumption and non-renewable energy consumption, respectively. Equation (5) can be parameterized as follows:

$$
\mathrm{CO}_{2 \text { it }}=\alpha \cdot Y_{i t}^{\beta 1} \cdot \mathrm{REC}_{\mathrm{it}}^{\beta 2} \cdot \mathrm{NREC}_{\mathrm{it}}^{\beta 3}
$$

The log transformation of the empirical equation is developed as follows:

$$
\log \mathrm{CO}_{2 \mathrm{it}}=\log \alpha+\beta 1 \cdot \log \mathrm{Y}_{\mathrm{it}}+\beta 2 \cdot \log \mathrm{REC}_{\mathrm{it}}+\beta 3 \cdot \log \mathrm{NREC}_{\mathrm{it}}+\varepsilon_{\mathrm{it}}+\gamma_{\mathrm{i}}
$$

Here, $\log \alpha$ is constant and $\beta 1, \beta 2, \beta 3$ are elasticities of $\mathrm{CO}_{2}$ emissions with respect to GDP, renewable energy consumption and non-renewable energy consumption respectively. $\varepsilon_{i t}$ is an error term and $\gamma_{\mathrm{i}}$ shows an individual effect.

In order to determine the long-run relationship among the variables, panel unit root test is needed to identify the status of stationarity of the variables. If proven stationary, the next step is to apply an appropriate panel co-integration technique. If, the variables are found to be co-integrated, then fully modified ordinary least square (FMOLS) and dynamic ordinary least square (DOLS) methods will be applied to check long-run elasticity. At the final stage of analysis there is a test for causality through the Dumitreschu and Hurlin pair-wise panel causality test.

\section{Results and Discussion}

The data set is a strongly balanced panel of 30 countries covering the period of 1994-2014 (20 years).

\subsection{Panel Unit Root Test}

In order to select the appropriate unit root test, it is crucial to test the cross-section dependence in the panel. The first-generation unit root tests (Levin and Lin, Im Pesran Shin, Hadri) tests are based on cross sectional independence hypothesis. However, the second-generation panel unit root tests are applicable when the panel has cross-sectional dependence. Pesaran (2004) cross-section dependence (CD) test is based on a simple average of all pair-wise correlation coefficients in the OLS residuals obtained from standard augmented Dickey-Fuller regressions for each variable in the panel [39]. Table 2 presents the result of Cross- section dependence (CD). 
Table 2. Cross-section dependence (CD) test.

\begin{tabular}{cccccc}
\hline $\mathbf{Y}$ & REC & NREC & K & L & CO $_{2}$ \\
\hline $82.75^{* * *}$ & $39.20^{* * *}$ & $59.21^{* * *}$ & $64.85^{* * *}$ & $93.33^{* * *}$ & $63.52^{* * *}$ \\
\hline$(0.000)$ & $(0.000)$ & $(0.000)$ & $(0.000)$ & $(0.000)$ & $(0.000)$ \\
\hline
\end{tabular}

Note: ${ }^{* * *}$ indicates the rejection of null hypothesis of no cross-sectional dependence at $1 \%$ level of significance. Here $\mathrm{Y}, \mathrm{REC}, \mathrm{NREC}, \mathrm{K}, \mathrm{L}$ and $\mathrm{CO}_{2}$ stand for GDP, renewable energy consumption, non-renewable energy consumption, capital, labour and $\mathrm{CO}_{2}$ emissions respectively.

The results provide the evidence of cross-section dependence in the panel.

So, here we have applied a second-generation panel unit root test e.g., cross-section augmented IPS (CIPS) test presented in Table 3, which considers both heterogeneity and cross-sectional dependence across the panel [40].

Table 3. Panel unit root test.

\begin{tabular}{ccccccc}
\hline & Y & REC & NREC & K & L & CO $_{2}$ \\
\hline Level & $0.922(0.800)$ & $3.127(0.999)$ & $3.605(0.999)$ & $0.980(0.792)$ & $1.734(0.959)$ & $0.758(0.690)$ \\
\hline First & $-2.924^{* * *}$ & $-2.904^{* * *}$ & $-3.612^{* * *}$ & $-1.173^{* *}$ & $-2.694^{* * *}$ & $-3.125^{* * *}$ \\
difference & $(0.002)$ & $(0.002)$ & $(0.000)$ & $(0.030)$ & $(0.004)$ & $(0.001)$ \\
\hline
\end{tabular}

Note: $* * * * *$ indicate rejection of null hypothesis at $5 \%$ and $1 \%$ level of significance resp. Cross-section augmented IPS (CIPS) test is applied using constant and trend with 1 lag. Here Y, REC, NREC, K, L and $\mathrm{CO}_{2}$ stand for GDP, renewable energy consumption, non-renewable energy consumption, capital, labour and $\mathrm{CO}_{2}$ emissions respectively.

The results show that taking first-differences turns the variables stationary from non-stationary at their levels. Stationary data suggests the possibility of the existence of long-run relationship among the variables.

\subsection{Panel Co-Integration Test}

In this paper, we used the Pedroni (1999 and 2004) panel co-integration test to check the existence of long-run co-integration among the dependent and independent variables. There are seven test statistics (panel v-statistic, panel $\varrho$-statistic, panel Phillips-Perron (PP)-statistic, panel Augmented Dicky-Fuller (ADF)-statistic, group $\varrho$-statistic, group PP-statistic, and group ADF-statistic) in this test. It is a comprehensive co-integration test that takes into account the heterogeneous intercepts and trend coefficients across cross-sections [41,42]. Tables 4 and 5 present the results of Pedroni panel co-integration test.

Table 4. Pedroni panel co-integration test results for model-I (dependent variable: output).

Alternative hypothesis: Common AR coefficients (Within-dimension).

\begin{tabular}{ccccc}
\hline & Statistics & Probability & $\begin{array}{l}\text { Weighted } \\
\text { Statistics }\end{array}$ & Probability \\
\hline Panel v-Statistic & 0.804310 & 0.2106 & 0.064938 & 0.4741 \\
Panel $\varrho$-Statistic & 4.941484 & 1.0000 & 4.115011 & 1.0000 \\
Panel PP-Statistic & $-1.46635^{* *}$ & 0.04417 & $-1.724000^{* *}$ & 0.0362 \\
Panel ADF-Statistic & $-3.713810^{* * *}$ & 0.0001 & $-1.902167^{* *}$ & 0.0286 \\
\hline
\end{tabular}

Alternative hypothesis: Individual AR coefficients (Between-dimension).

\begin{tabular}{ccc}
\hline & Statistics & Probability \\
\hline Group Q-Statistic & 6.183689 & 1.0000 \\
Group PP-Statistic & $-3.057068^{* * *}$ & 0.0011 \\
Group ADF-Statistic & $-1.314386^{* *}$ & 0.0244 \\
\hline
\end{tabular}

Notes: Newey-West automatic bandwidth selection with Bartlett Kernel. ${ }^{* *}$ and ${ }^{* * *}$ denote rejection of null hypothesis of no co-integration at $5 \%$ and $1 \%$ level significance resp. 
Table 5. Pedroni panel co-integration test results for model-II (Dependent variable: $\mathrm{CO}_{2}$ emission).

Alternative hypothesis: Common AR coefficients (Within-dimension).

\begin{tabular}{ccccc}
\hline & Statistics & Probability & $\begin{array}{l}\text { Weighted } \\
\text { Statistics }\end{array}$ & Probability \\
\hline Panel v-Statistic & $0.686047^{* *}$ & 0.2463 & 1.909063 & 0.9719 \\
Panel @-Statistic & $1.947982^{* * *}$ & 0.0257 & 1.066686 & 0.1431 \\
Panel PP-Statistic & $-7.742661^{* * *}$ & 0.0000 & $-6.996249^{* * *}$ & 0.0000 \\
Panel ADF-Statistic & $-4.600051^{* * *}$ & 0.0000 & $-5.659427^{* * *}$ & 0.0000 \\
\hline
\end{tabular}

Alternative hypothesis: Individual AR coefficients (Between-dimension).

\begin{tabular}{ccc}
\hline & Statistics & Probability \\
\hline Group Q-Statistic & 0.535848 & 0.7040 \\
Group PP-Statistic & $-8.371437^{* * *}$ & 0.0000 \\
Group ADF-Statistic & $-5.158757^{* * *}$ & 0.0001 \\
\hline
\end{tabular}

Notes: Newey West automatic bandwidth selection with Bartlett Kernel. ${ }^{* *}$ and ${ }^{* * *}$ denote rejection of null hypothesis of no co-integration at $5 \%$ and $1 \%$ level of significance respectively.

Here, four out of seven test statistics confirm the presence of co-integration among the variables for both the models (e.g., model-I and model-II), confirming the existence of long-run equilibrium relationship among the variables in both cases.

\subsection{Fully Modified Ordinary Least Square (FMOLS)}

The long-run elasticity for the panel in this study is estimated using Fully Modified Ordinary Least Square (FMOLS) model. Pedroni (1996) introduced fully modified OLS (FMOLS) to tackle the problems of simultaneity bias, non-exogeneity and serial correlation and obtain asymptotically efficient consistent estimates in panel series $[43,44]$. Table 6 presents the FMOLS long-run elasticity results for panel.

Table 6. FMOLS long-run elasticity results for panel.

\begin{tabular}{|c|c|c|c|}
\hline Dependent Variable & Independent Variable & Co-Efficient & Probability \\
\hline \multicolumn{4}{|c|}{ Model-I } \\
\hline \multirow{4}{*}{$\log Y$} & Log REC & $0.176^{* * *}$ & 0.002 \\
\hline & Log NREC & $0.253^{* * *}$ & 0.001 \\
\hline & $\log L$ & $0.702 * * *$ & 0.000 \\
\hline & $\log K$ & $0.368^{* * *}$ & 0.000 \\
\hline \multicolumn{4}{|c|}{ Model-II } \\
\hline \multirow{3}{*}{$\log \mathrm{CO}_{2}$} & $\log Y$ & $0.436^{* * *}$ & 0.000 \\
\hline & Log REC & $-0.107^{* *}$ & 0.019 \\
\hline & Log NREC & $0.558^{* * *}$ & 0.000 \\
\hline
\end{tabular}

Note: ${ }^{* *}$ and ${ }^{* * *}$ represent $5 \%$ and $1 \%$ level of significance respectively. Here, Y, REC, NREC, K, L and $\mathrm{CO}_{2}$ stand for GDP, renewable energy consumption, non-renewable energy consumption, capital, labour and $\mathrm{CO}_{2}$ emissions respectively.

The fully modified ordinary least square (FMOLS) test for output (model-I) shows that, increase in renewable energy consumption by $1 \%$ will increase output by $0.18 \%$. While a $1 \%$ increase in non-renewable energy consumption will lead to a $0.25 \%$ increase in output. The findings of long run output elasticity in FMOLS suggests that renewable and non-renewable energy consumption both cause positive and significant impact on output along with labour and capital.

The fully modified ordinary least square (FMOLS) test for $\mathrm{CO}_{2}$ emission (model-II) shows that increase in GDP by $1 \%$ will increase $\mathrm{CO}_{2}$ emissions by $0.44 \%$ while, increase in renewable energy consumption by $1 \%$ will decrease the emission by $0.11 \%$. However, a $1 \%$ increase in non-renewable 
energy consumption causes a $0.56 \%$ increase in $\mathrm{CO}_{2}$ emission. From the findings it is seen that, non-renewable energy consumption contributes to the increase in $\mathrm{CO}_{2}$ emission more than the GDP growth.

\subsection{Dynamic Ordinary Least Square (DOLS)}

The main reasons for choosing DOLS are, first, it is robust to small samples and outperforms both Ordinary Least Square (OLS) and Fully Modified Ordinary Least Square (FMOLS) estimators in terms of unbiased estimation for finite samples, and second, the superiority of DOLS estimator to other estimators in case of controlling endogeneity bias [45]. Table 7 presents the DOLS long-run elasticity results for panel.

Table 7. Dynamic ordinary least square (DOLS) long-run elasticity results for panel.

\begin{tabular}{|c|c|c|c|}
\hline Dependent Variable & Independent Variable & Co-Efficient & Probability \\
\hline \multicolumn{4}{|c|}{ Model-I } \\
\hline \multirow{4}{*}{$\log Y$} & Log REC & $0.201^{* * *}$ & 0.002 \\
\hline & Log NREC & $0.285^{* * *}$ & 0.000 \\
\hline & $\log \mathrm{L}$ & $0.533^{* * *}$ & 0.000 \\
\hline & $\log K$ & $0.254^{* * *}$ & 0.000 \\
\hline \multicolumn{4}{|c|}{ Model-II } \\
\hline \multirow{3}{*}{$\log \mathrm{CO}_{2}$} & $\log Y$ & $0.378^{* * *}$ & 0.000 \\
\hline & Log REC & $-0.103^{* *}$ & 0.047 \\
\hline & Log NREC & $0.662^{* * *}$ & 0.000 \\
\hline
\end{tabular}

Note: ${ }^{* *}$ and ${ }^{* * *}$ represent $5 \%$ and $1 \%$ level of significance respectively. Here, Y, REC, NREC, K, L and $\mathrm{CO}_{2}$ stand for GDP, renewable energy consumption, non-renewable energy consumption, capital, labour and $\mathrm{CO}_{2}$ emissions respectively.

The dynamic ordinary least square (DOLS) test for output (model-I) shows that, increase in renewable energy consumption by $1 \%$ will increase output by $0.20 \%$, while increase in non-renewable energy consumption by $1 \%$ will increase output by $0.28 \%$.

Dynamic ordinary least square (DOLS) test for $\mathrm{CO}_{2}$ emission (model-II) shows that a $1 \%$ increase in GDP will increase $\mathrm{CO}_{2}$ emissions by $0.38 \%$ while a $1 \%$ increase in renewable energy consumption by will decrease emission by $0.10 \%$. An increase in non-renewable energy consumption by $1 \%$ will lead to a $0.66 \%$ increase of $\mathrm{CO}_{2}$ emissions. From the findings, it is seen that, non-renewable energy consumption contributes more in the increase of $\mathrm{CO}_{2}$ emissions compared to GDP.

Based on the findings from the FMOLS and DOLS tests, it is seen that both renewable and non-renewable energy consumption play important roles in economic growth. The outcomes are positive for both types of energy consumption. Important fact is, renewable energy consumption has the future prospect in ensuring sustainable economic growth, which is not possible with non-renewable energy consumption. Additionally, renewable energy consumption is found effective in reducing $\mathrm{CO}_{2}$ emissions. From the findings of both FMOLS and DOLS it can be said that, in the long-run, renewable energy consumption can ensure green growth in emerging and developing countries.

\subsection{Country-Specific FMOLS Long-Run Elasticity Analysis}

This section will test the long-run elasticity for individual countries of different regions through country specific FMOLS method, which will give more specific outcomes for the countries of different regions. Table 8 presents country-specific FMOLS long-run output elasticity results. 
Table 8. Country-specific FMOLS long-run output elasticity results.

\begin{tabular}{|c|c|c|c|c|c|c|c|}
\hline Region & Country & Log REC & Log NREC & $\log L$ & $\log K$ & $\mathbf{R}^{2}$ & Adj. $R^{2}$ \\
\hline \multirow{6}{*}{ South Asia } & India & $1.390 * * *$ & $0.618^{* * *}$ & $0.773^{* * *}$ & 0.044 & 0.999 & 0.999 \\
\hline & Bangladesh & $0.542 * * *$ & -0.031 & $0.799 * * *$ & $0.823^{* * *}$ & 0.999 & 0.999 \\
\hline & Pakistan & $1.722 * * *$ & $0.210 *$ & 0.265 & $0.190 * * *$ & 0.997 & 0.996 \\
\hline & Sri Lanka & -0.114 & $0.276^{* *}$ & 0.391 & $0.669^{* * *}$ & 0.987 & 0.983 \\
\hline & Nepal & $0.379 * *$ & 0.031 & $1.259^{* * *}$ & 0.140 ** & 0.996 & 0.994 \\
\hline & Bhutan & $1.900^{* * *}$ & $0.073 * * *$ & $0.625^{* * *}$ & $0.034^{* *}$ & 0.998 & 0.998 \\
\hline \multirow{6}{*}{ Asia } & Malaysia & $-0.179 * * *$ & $0.368^{* * *}$ & $0.889 * * *$ & $0.180^{* * *}$ & 0.996 & 0.995 \\
\hline & Indonesia & $0.396^{* * *}$ & -0.046 & $0.992 * * *$ & $0.476^{* * *}$ & 0.996 & 0.994 \\
\hline & China & $0.501^{* *}$ & 0.127 & $1.106^{* *}$ & $0.721^{* * *}$ & 0.997 & 0.997 \\
\hline & Philippine & -0.040 & $0.318^{* *}$ & $1.030^{* * *}$ & $0.553^{* * *}$ & 0.997 & 0.966 \\
\hline & Thailand & $0.373^{* * *}$ & $0.307^{* *}$ & $0.986^{* * *}$ & $0.087^{* * *}$ & 0.994 & 0.992 \\
\hline & Korea & -0.032 & $0.112 * * *$ & $4.090^{* * *}$ & 0.110 & 0.988 & 0.984 \\
\hline \multirow{5}{*}{ Latin America } & Columbia & 0.058 & $0.617^{* * *}$ & $0.643^{* * *}$ & $0.127^{* * *}$ & 0.995 & 0.994 \\
\hline & Ecuador & 0.019 & $0.347 * * *$ & $0.385^{* * *}$ & $0.239 * * *$ & 0.990 & 0.988 \\
\hline & Peru & 0.112 & $0.208^{* *}$ & $0.736^{* *}$ & $0.227 * * *$ & 0.995 & 0.994 \\
\hline & Costa Rica & $0.105^{* *}$ & -0.118 & $0.893^{* * *}$ & 0.342 & 0.982 & 0.977 \\
\hline & Bolivia & 0.074 & $1.853^{* * *}$ & $1.179^{* * *}$ & $1.194^{* * *}$ & 0.996 & 0.995 \\
\hline \multirow{11}{*}{ Africa } & Ghana & $0.516^{* * *}$ & $0.186^{* *}$ & $2.780 * * *$ & $0.195 * *$ & 0.989 & 0.987 \\
\hline & Mozambique & 0.026 & -0.083 & $3.116^{* * *}$ & 0.040 & 0.992 & 0.990 \\
\hline & Senegal & -0.035 & $0.274^{* *}$ & 0.366 & 0.243 & 0.990 & 0.987 \\
\hline & Chad & $-3.608 * *$ & $0.313^{* * *}$ & $3.101 * * *$ & 0.056 & 0.980 & 0.976 \\
\hline & Nigeria & $0.210^{* *}$ & $0.478^{* * *}$ & 0.232 & $0.321^{* * *}$ & 0.985 & 0.981 \\
\hline & Kenya & 0.002 & -0.201 & 0.631 & $0.369^{* * *}$ & 0.990 & 0.988 \\
\hline & Zimbabwe & $1.976^{* * *}$ & $1.036^{* * *}$ & 0.951 & $0.062^{* * *}$ & 0.887 & 0.857 \\
\hline & Tunisia & $0.281 * * *$ & 0.281 ** & $1.290 * * *$ & 0.063 & 0.997 & 0.996 \\
\hline & South Africa & $1.072 * * *$ & 0.0035 & 0.006 & $0.269^{* * *}$ & 0.997 & 0.996 \\
\hline & Uganda & $-0.253 * *$ & -0.082 & $1.586^{* * *}$ & $0.228^{* * *}$ & 0.997 & 0.996 \\
\hline & Cameroon & $0.134^{* *}$ & -0.054 & $1.408^{* * *}$ & 0.010 & 0.997 & 0.996 \\
\hline \multirow{2}{*}{ Caribbean } & Haiti & 0.018 & -0.038 & 0.100 & $0.190 * * *$ & 0.891 & 0.862 \\
\hline & Jamaica & -0.050 & $0.074^{* * *}$ & $0.632^{* * *}$ & $0.188^{* * *}$ & 0.913 & 0.890 \\
\hline
\end{tabular}

Note: ${ }^{*}, * * * *$ denotes significance levels of $10 \%, 5 \%$ and $1 \%$ respectively. Here, REC, NREC, $\mathrm{L}$ and $\mathrm{K}$ stand for renewable energy consumption, non-renewable energy consumption, labour and capital respectively.

In the country-specific long-run output elasticity results for 30 emerging and developing countries, 18 show significant long-run relationship between renewable energy and economic output. Of these 18 countries, 15 show significant and positive relation and 3 have a significant but negative relation between renewable energy and economic output. Among these 3 countries, 2 are from the African region (Uganda, Chad) and another from the Asian region (Malaysia). The present characteristics of energy consumption of these countries show a dependence on fossil fuel energy and limited investment in renewable energy sector. This is resulting in slow deployment of renewable energy. From our results, it is seen that, the impact of renewable energy consumption on economic growth is more than non-renewable energy consumption for Asian, South-Asian and most of the African countries (Ghana, Tunisia, South Africa, Zimbabwe and Cameroon). But for the Latin American and the Caribbean countries, it can be said that economic growth depends on non-renewable energy consumption. Renewable energy consumption in the selected countries of these two regions are still at the initial stage. Table 9 presents the country-specific FMOLS long-run $\mathrm{CO}_{2}$ elasticity results. 
Table 9. Country-specific FMOLS long-run $\mathrm{CO}_{2}$ elasticity results.

\begin{tabular}{|c|c|c|c|c|c|c|}
\hline Region & Country & $\log Y$ & Log REC & Log NREC & $\mathbf{R}^{2}$ & Adj. $\mathbf{R}^{2}$ \\
\hline \multirow{6}{*}{ South Asia } & India & 0.394 * & -1.237 & $0.935^{* * *}$ & 0.995 & 0.994 \\
\hline & Bangladesh & 0.040 & -0.000 & $1.133^{* * *}$ & 0.996 & 0.995 \\
\hline & Pakistan & 0.044 & 0.093 & $1.127^{* * *}$ & 0.993 & 0.991 \\
\hline & Sri Lanka & $0.312^{* * *}$ & $-0.702 * *$ & $1.159^{* * *}$ & 0.981 & 0.977 \\
\hline & Nepal & $2.172 * * *$ & $-2.752 * * *$ & $0.716^{* * *}$ & 0.993 & 0.921 \\
\hline & Bhutan & $0.603 * *$ & $1.851 *$ & $1.114^{* * *}$ & 0.976 & 0.970 \\
\hline \multirow{6}{*}{ Asia } & Malaysia & $1.103^{* * *}$ & $-1.295^{* * *}$ & -0.137 & 0.957 & 0.949 \\
\hline & Indonesia & $0.738^{* * *}$ & -0.973 & 0.798 & 0.902 & 0.896 \\
\hline & China & 0.041 & -0.144 & $1.084^{* * *}$ & 0.997 & 0.996 \\
\hline & Philippine & $0.393^{* * *}$ & 0.159 & $0.796^{* * *}$ & 0.926 & 0.912 \\
\hline & Thailand & 0.093 & $-0.153^{* *}$ & $1.138^{* * *}$ & 0.995 & 0.994 \\
\hline & Korea & $0.598^{* * *}$ & $-0.167^{* * *}$ & $0.865^{* * *}$ & 0.965 & 0.959 \\
\hline \multirow{5}{*}{$\begin{array}{c}\text { Latin } \\
\text { America }\end{array}$} & Columbia & 0.055 & 0.164 & $1.458^{* * *}$ & 0.917 & 0.902 \\
\hline & Ecuador & $1.032 * *$ & -0.187 & 0.120 & 0.913 & 0.897 \\
\hline & Peru & $0.774^{* * *}$ & 0.047 & 0.329 & 0.950 & 0.937 \\
\hline & Costa Rica & 0.023 & $0.235^{* * *}$ & $0.758^{* *}$ & 0.952 & 0.944 \\
\hline & Bolivia & $0.817^{* * *}$ & 0.385 & 0.032 & 0.907 & 0.890 \\
\hline \multirow{11}{*}{ Africa } & Ghana & $0.764^{* *}$ & 0.202 & 0.118 & 0.906 & 0.889 \\
\hline & Mozambique & 0.216 & -0.529 & $1.730^{* * *}$ & 0.961 & 0.953 \\
\hline & Chad & $0.393^{* *}$ & 1.075 & $0.418^{* * *}$ & 0.990 & 0.989 \\
\hline & Nigeria & $0.881^{* * *}$ & $-0.661^{* * *}$ & 0.143 & 0.977 & 0.973 \\
\hline & Kenya & $0.841 *$ & $-1.790^{* * *}$ & $1.180^{* * *}$ & 0.936 & 0.924 \\
\hline & Tunisia & $0.444^{* * *}$ & $-0.220 * * *$ & $0.620^{* * *}$ & 0.993 & 0.991 \\
\hline & South Africa & 0.457 & $-0.896^{* *}$ & $0.739 * * *$ & 0.923 & 0.909 \\
\hline & Uganda & $0.654^{* *}$ & 0.088 & $0.646^{* *}$ & 0.993 & 0.992 \\
\hline & Cameroon & 0.420 & 0.527 & $1.180^{* * *}$ & 0.910 & 0.897 \\
\hline & Senegal & $2.00^{* * *}$ & 0.251 & $0.834^{* * *}$ & 0.830 & 0.800 \\
\hline & Zimbabwe & 0.042 & -0.156 & $1.230^{* * *}$ & 0.824 & 0.792 \\
\hline \multirow{2}{*}{ Caribbean } & Haiti & 0.245 & $0.378^{* * *}$ & $0.761^{* * *}$ & 0.991 & 0.990 \\
\hline & Jamaica & $2.224^{* * *}$ & -0.142 & $0.718^{* * *}$ & 0.892 & 0.863 \\
\hline
\end{tabular}

Note: ${ }^{*}{ }^{* *}$ and ${ }^{* * *}$ denote significance levels of $10 \%, 5 \%$ and $1 \%$ respectively. Here, Y, REC and NREC stand for GDP, renewable energy consumption and non-renewable energy consumption respectively.

For the country specific long-run elasticity results for $\mathrm{CO}_{2}$ emissions, out of 30 developing countries, 12 show significant results. Of them, 9 show the empirical evidence that, renewable energy consumption will reduce $\mathrm{CO}_{2}$ emission. But for 3 countries, the increase in renewable energy consumption leads to a slight increase in $\mathrm{CO}_{2}$ emission, although the rate is lower than that of non-renewable energy consumption. Depending on the nature and relative importance of renewable energy sources in an economy, the results may change from country to country. These countries have a common practice of using energy mixes (both renewable energy and fossil fuel energy in parallel) like solar photovoltaic (PV) for electricity and gas stove for cooking in daily household life. Sometimes, problems arise from the variation in renewable energy technology development, lack of knowledge in operation, fault in designing or installation of plants. From the results we can also see that, in case of South Asian, Asian, Latin American and African countries, both GDP growth and non-renewable energy consumption cause the increase in $\mathrm{CO}_{2}$ emissions. While, in case of the Caribbean countries non-renewable energy consumption plays the dominant role in increasing $\mathrm{CO}_{2}$ emissions.

\subsection{Pair-Wise Dumitreschu and Hurlin Causality Test}

In order to examine the direction of short-run causality among the variables, we have used the panel causality test based on Dumitreschu and Hurlin (2012). According to Dumitreschu and Hurlin (2012), the test value converges to a normal distribution under the homogeneous non-causality 
hypothesis. The main advantage of this test is, it assumes all coefficients are different across the cross section [46]. Table 10 presents the pair-wise Dumitreschu and Hurlin causality test.

The data series is stationary and the Schwarz information criterion (SIC) is used to determine the appropriate lag length.

Table 10. Pair-wise Dumitreschu and Hurlin causality test.

\begin{tabular}{ccc}
\hline Null Hypothesis & Zbar-Stat & Probability \\
\hline Log REC does not homogeneously cause Log Y & $2.257^{* *}$ & 0.0240 \\
Log Y does not homogeneously cause Log REC & $4.427^{* * *}$ & 0.0001 \\
Log NREC does not homogeneously cause Log Y & $1.996^{* *}$ & 0.0459 \\
Log Y does not homogeneously cause Log NREC & $6.464^{* * *}$ & 0.0000 \\
Log K does not homogeneously cause Log Y & $3.306^{* * *}$ & 0.0009 \\
Log Y does not homogeneously cause Log K & $9.349^{* * *}$ & 0.0000 \\
Log L does not homogeneously cause Log Y & $4.942^{* * *}$ & 0.0000 \\
Log Y does not homogeneously cause Log L & $7.848^{* * *}$ & 0.0000 \\
Log NREC does not homogeneously cause Log REC & $2.978^{* * *}$ & 0.0029 \\
Log REC does not homogeneously cause Log NREC & $2.830^{* * *}$ & 0.0047 \\
Log K does not homogeneously cause Log REC & 0.904 & 0.3661 \\
Log REC does not homogeneously cause Log K & $3.488^{* * *}$ & 0.0005 \\
Log L does not homogeneously cause Log REC & $30.49^{* * *}$ & 0.0000 \\
Log REC does not homogeneously cause Log L & $3.817^{* * *}$ & 0.0010 \\
Log K does not homogeneously cause Log NREC & $5.971^{* * *}$ & 0.0000 \\
Log NREC does not homogeneously cause Log K & $2.248^{* * *}$ & 0.0246 \\
Log L does not homogeneously cause Log NREC & $7.069^{* * *}$ & 0.0000 \\
Log NREC does not homogeneously cause Log L & $5.446^{* * *}$ & 0.0000 \\
Log L does not homogeneously cause Log K & $7.993^{* * *}$ & 0.0000 \\
Log K does not homogeneously cause Log L & $3.717^{* * *}$ & 0.0002 \\
Log Y does not homogeneously Cause Log CO 2 & $10.748^{* * *}$ & 0.0000 \\
Log CO 2 does not homogeneously Cause Log Y & $3.203^{* * *}$ & 0.0014 \\
Log REC does not homogeneously Cause Log CO 2 & 1.396 & 0.1627 \\
Log CO 2 does not homogeneously Cause Log REC & $2.000^{* *}$ & 0.0455 \\
Log NREC does not homogeneously Cause Log CO 2 & $4.822^{* * *}$ & 0.0000 \\
Log CO 2 does not homogeneously Cause Log NREC & $2.475^{* * *}$ & 0.0133 \\
\hline
\end{tabular}

Note: ${ }^{* *}$ and ${ }^{* * *}$ denote significance level at $5 \%$ and at $1 \%$ resp. Here, $\mathrm{Y}, \mathrm{REC}, \mathrm{NREC}, \mathrm{K}, \mathrm{L}$ and $\mathrm{CO}_{2}$ stand for GDP, renewable energy consumption, non-renewable energy consumption, capital, labour and $\mathrm{CO}_{2}$ emissions respectively.

In case of pair-wise relationships above, there is bi-directional causality between GDP and all other inputs (e.g., energy consumption, labour force and capital). Here, the important finding is the existence of feedback hypothesis between renewable energy consumption and economic growth. This indicates that economic growth in these countries contributes to the renewable energy investment and this in turn facilitates production and economic growth or vice versa. This is a positive sign for taking initiatives for increasing renewable energy investments for sustainable economic growth.

Both GDP and non-renewable energy consumption have bi-directional causality with $\mathrm{CO}_{2}$ emissions. There is unidirectional causality between renewable energy consumption and $\mathrm{CO}_{2}$ emissions. The findings indicate that high consumption of non-renewable energy will increase $\mathrm{CO}_{2}$ emissions. In response to it, GDP can be used to increase investments in renewable energy sector, which will contribute to the reduction of $\mathrm{CO}_{2}$ emissions in the long-run.

\section{Conclusions, Limitations and Further Scope of the Study}

At present, renewable energy projects are becoming vital in the energy mixes of most of the countries. The results of this paper also show that, renewable energy can benefit the economic growth and reduce $\mathrm{CO}_{2}$ emissions in the long run. In order to ensure sustainable economic development, emerging and developing countries should focus on increasing investments in the renewable energy sector. Successful implementation of renewable energy projects depends on adopting a suitable 'policy 
package', rather than choosing stand-alone policies. At present the popularly practiced renewable energy policies are: subsidy, renewable portfolio standards as a cost-effective option to reduce initial cost of technology installation, low interest loans, green certificates as tradeable assets for electricity generation from renewable sources and feed in tariff offering fixed and guaranteed price for electricity generation from renewable sources [47].

From our findings, the countries where the impact of renewable energy consumption on economic growth is positive and more than that of non-renewable energy consumption have already shifted their investment focus to the renewable energy sector and passed the take-off stage. They can take advanced policy initiatives, e.g., feed-in tariffs, renewable portfolio standards, green certificates and fossil fuel divestment for long-term economic development. Countries like China, India and South Africa have undertaken advanced measures in their renewable energy policy package. For other countries that are in the take-off stage of renewable energy investments, can adopt subsidies, tax incentives, market development initiatives and establish public-private partnership for financing renewable energy projects at low interest rate as the possible policy options. Countries need to increase their allocations in research and development for promoting low-cost innovative technologies.

The real set-up in these emerging and developing economies is surrounded by socio-economic, political and market barriers. In order to facilitate renewable energy sector, it is important to reduce the risk of investment and change the difficult procedures of getting a loan. Governments and the private sector should establish public-private partnership to remove the barriers and reduce the risks in renewable energy investment.

In this paper the authors include the renewable energy sources as defined by the U.S. Energy Information Administration (EIA), e.g., solar, wind, hydropower, biofuel and biomass to analyse the impact of renewable energy consumption on economic growth and $\mathrm{CO}_{2}$ emissions. This study does not include 'nuclear' in the 'renewable' category following the definition of the EIA. But as a further expansion of the study, the authors would like to analyse 'the nexus between power generation from nuclear energy and economic growth'.

The study takes into account the renewable energy produced from 'biofuels'. Biofuels are derived from corn, palm and other crop-based sources. The main problem of consuming biofuels is deforestation, which has consequences like social dislocation, loss of biodiversity and displacement of food crops (Asian Development outlook 2013: Asia's energy challenge, p-85) [48]. Addressing these problems, 'the efficiency of biofuels in ensuring sustainable development' can be another field of further study.

Finally, this study employs the Cobb-Douglas function, which has its own limitations. Other functional forms e.g., the constant elasticity of substitution (CES) can be more flexible but is not transformable in to log-linear form. This study deals with the log-linear transformation so, we have to use the Cobb-Douglas function.

Author Contributions: M.M.A. mainly worked for data set preparation, econometric analysis, and writing of the paper, K.S. mainly developed conceptual and methodological framework of the paper. Conceptualization, K.S. and M.M.A.; methodology, K.S.; data curation, M.M.A.; formal analysis, M.M.A.; resources, K.S. and M.M.A.; writing, original draft preparation, M.M.A.; editing, K.S.; supervision, K.S.; funding acquisition: K.S.

Funding: This research was partly funded by Japan Society for the Promotion of Science (JSPS), Grant No. 15K00645.

Conflicts of Interest: The authors declare no conflict of interest.

\section{References}

1. The Renewables 2018 Global Status Report. Available online: http://www.ren21.net/gsr-2018/ (accessed on 3 April 2019).

2. Stern, D.I.; Cleveland, C.J. Energy and Economic Growth. Available online: https://econpapers.repec.org/ paper/rpirpiwpe/0410.htm (accessed on 3 April 2019).

3. Tugcu, C.T.; Ozturk, I.; Aslan, A. Renewable and non-renewable energy consumption and economic growth relationship revisited: Evidence from G7 countries. Energy Econ. 2012, 34, 1942-1950. [CrossRef] 
4. Kraft, J.; Kraft, A. On the relationship between energy and GNP. J. Energy Dev. 1978, 3, 401-403.

5. Soytas, U.; Sari, R.; Ozdemir, O. Energy Consumption and GDP Relations in Turkey: A Co-integration and Vector Error Correction Analysis. Glob. Bus. Technol. Assoc. 2001, 1, 838-844.

6. Ewing, B.T.; Sari, R.; Soytas, U. Disaggregate energy consumption and industrial output in the United States. Energy Policy 2007, 35, 1274-1281. [CrossRef]

7. Akinlo, A.E. Energy consumption and economic growth: Evidence from 11 Sub-Sahara African countries. Energy Econ. 2008, 30, 2391-2400. [CrossRef]

8. Lee, C.-C.; Chang, C.-P. The impact of energy consumption on economic growth: Evidence from linear and nonlinear models in Taiwan. Energy 2007, 32, 2282-2294. [CrossRef]

9. Sadorosky, P. Renewable energy consumption and income in emerging economies. Energy Policy 2009, 37, 4021-4028. [CrossRef]

10. Apergis, N.; Payne, J.E. Renewable energy consumption and economic growth: Evidence from a panel of OECD countries. Energy Policy 2010, 38, 656-660. [CrossRef]

11. Payne, J.E. Survey of the international evidence on the causal relationship between energy consumption and growth. J. Econ. Stud. 2010, 37, 53-95. [CrossRef]

12. Apergis, N.; Payne, J.E. The renewable energy consumption-growth nexus in Central America. Appl. Energy 2011, 88, 343-347. [CrossRef]

13. Menegaki, A.N. Growth and renewable energy in Europe: A random effect model with evidence for neutrality hypothesis. Energy Econ. 2011, 33, 257-263. [CrossRef]

14. Fang, Y. Economic welfare impacts from renewable energy consumption: The China experience. Renew. Sustain. Energy Rev. 2011, 15, 5120-5128. [CrossRef]

15. Tiwari, A.K. A structural VAR analysis of renewable energy consumption, real GDP and $\mathrm{CO}_{2}$ emissions: Evidence from India. Econ. Bull. 2011, 31, 1793-1806.

16. Shahbaz, M.; Zeshan, M.; Afza, T. Is Energy Consumption Effective to Spur Economic Growth in Pakistan? New Evidence from Bounds Test to Level Relationships and Granger Causality Tests. Econ. Model. 2012, 29, 2310-2319. [CrossRef]

17. Bildirici, M.E. Relationship between biomass energy and economic growth in transition countries: Panel ARDL approach. GCB Bio Energy 2014, 6, 717-726. [CrossRef]

18. Bildirici, M.E.; Ozaksoy, F. The relationship between economic growth and biomass energy consumption in some European countries. J. Renew. Sustain. Energy 2013. [CrossRef]

19. Caraiani, C.; Lungu, C.I.; Dascalu, C. Energy consumption and GDP causality: A three step analysis for emerging European countries. Renew. Sustain. Energy Rev. 2015, 44, 198-210. [CrossRef]

20. Bildirici, M.; Ersin, O. An investigation of the relationship between the biomass energy consumption, economic growth and oil prices. Proced. Soc. Behav. Sci. 2015, 210, 203-212. [CrossRef]

21. Bloch, H.; Rafiq, S.; Salim, R. Economic growth with coal, oil and renewable energy consumption in China: Prospects for fuel substitution. Econ. Model. 2015, 44, 104-115. [CrossRef]

22. Paramati, S.R.; Apergis, N.; Ummalla, M. Dynamics of renewable energy consumption and economic activities across the agriculture, industry and service sectors: evidence in the perspective of sustainable development. Environ. Sci. Pollut. Res. 2018, 25, 1375-1387. [CrossRef]

23. Kaygusuz, K.; Yuksek, O.; Sari, A. Renewable energy sources in the European Union: Markets and capacity. Econ. Plan. Policy 2007, 2, 19-29. [CrossRef]

24. Menyah, K.; Wolde-Rufael, Y. $\mathrm{CO}_{2}$ emissions, nuclear energy, renewable energy and economic growth in the US. Energy Policy 2010, 38, 2911-2915. [CrossRef]

25. Apergis, N.; Payne, J.E.; Menyah, K.; Wolde-Rufael, Y. On the causal dynamics between emissions, nuclear energy, renewable energy and economic growth. Ecol. Econ. 2010, 69, 2255-2260. [CrossRef]

26. Odhiambo, N.M. Economic growth and carbon emissions in South Africa: An empirical investigation. Int. Bus. Econ. Res. J. 2011. [CrossRef]

27. Farhani, S. Renewable energy consumption, economic growth and $\mathrm{CO}_{2}$ emissions: evidence from selected MENA countries. Energy Econ. Lett. 2013, 1, 24-41.

28. Omri, A. $\mathrm{CO}_{2}$ emissions, energy consumption and economic growth nexus in MENA countries: Evidence from simultaneous equations models. Energy Econ. 2013, 40, 657-664. [CrossRef] 
29. Zeb, R.; Salar, L.; Awan, U.; Zaman, K.; Shahbaz, M. Causal links between renewable energy, environmental degradation and economic growth in selected SAARC countries: Progress towards green economy. Renew. Energy 2014, 71, 123-132. [CrossRef]

30. Apergis, N.; Payne, J.E. The causal dynamics between renewable energy, real GDP, emissions and oil prices: evidence from OECD countries. Appl. Econ. 2014, 46, 4519-4525. [CrossRef]

31. Mbarek, M.B.; Ali, N.B.; Feki, R. Causality relationship between $\mathrm{CO}_{2}$ emissions, GDP and energy intensity in Tunisia. Environ. Dev. Sustain. 2014, 16, 1253-1262. [CrossRef]

32. Bouznit, M.; Pablo-Romero, M.d.P. $\mathrm{CO}_{2}$ emission and economic growth in Algeria. Energy Policy 2016, 96, 93-104. [CrossRef]

33. Mitic, P.; Ivanovic, O.M.; Zravkovic, A. A co-integration analysis of real GDP and CO2 emissions in transitional countries. Sustainability 2017, 9, 568. [CrossRef]

34. Renewable Energy Explained. Available online: https://www.eia.gov/energyexplained/?page=renewable home (accessed on 27 July 2019).

35. Sustainable Development 2015. Available online: https:/www.sustainabledevelopment2015.org/ AdvocacyToolkit/index.php/earth-summit-history/historical-documents/92-our-common-future (accessed on 27 July 2019).

36. Barbier, E.B. The concept of sustainable economic development. Environ. Conserv. 1987, 14, 101-110. [CrossRef]

37. Asia Leads the Charge in Growth of Renewable Energy. Available online: https:/asia.nikkei.com/Economy/ Asia-leads-the-charge-in-growth-of-renewable-energy (accessed on 13 May 2019).

38. Cobb, C.W.; Douglas, P.H. A Theory of Production. Available online: http://www.institutodeestudiosurbanos. info/dmdocuments/cendocieu/Especializacion_Mercados/Documentos_Cursos/Theory_Production-Cobb_ Charles-1928.pdf (accessed on 22 July 2019).

39. Pesaran, M.H. General diagnostic tests for cross section dependence in panels. J. Econ. 2004, 69, 1229.

40. Pesaran, M.H. A simple panel unit root test in the presence of cross-section dependence. J. Appl. Econ. 2007, 22, 265-312. [CrossRef]

41. Pedroni, P. Panel Co-integration: Asymptotic and finite samples properties of pooled time series Tests with an application to the PPP hypothesis. Econ. Theory 2004, 20, 597-625. [CrossRef]

42. Pedroni, P. Critical values for co-integration tests in heterogeneous panels with multiple regressors. Oxford Bull. Econ. Stat. 1999, 61, 653-670. [CrossRef]

43. Pedroni, P. Fully Modified OLS for heterogeneous co-integration Panel. Adv. Econ. 2001, 15, 93-130.

44. Pedroni, P. Fully Modified OLS for Heterogeneous Co-Integrated Panels and The Case of Purchasing Power Parity. Available online: https://web.williams.edu/Economics/pedroni/WP-96-20.pdf (accessed on 27 July 2019).

45. Stock, J.H.; Watson, M.W. A simple estimator of co-integrating vectors in higher Order integrated systems. Economics 1993, 61, 783-820.

46. Dumitrescu, E.-I.; Hurlin, C. Testing for Granger non-causality in heterogeneous panels. Econ. Model. 2012, 29, 1450-1460. [CrossRef]

47. Abdmouleh, Z.; Alammari, R.A.M.; Gastli, A. Review of policies encouraging renewable energy integration and best practices. Renew. Sustain. Energy Rev. 2015, 45, 249-262. [CrossRef]

48. Asian Development Outlook 2013. Available online: https://www.adb.org/sites/default/files/publication/ 30205/ado2013_1.pdf (accessed on 20 July 2019).

(C) 2019 by the authors. Licensee MDPI, Basel, Switzerland. This article is an open access article distributed under the terms and conditions of the Creative Commons Attribution (CC BY) license (http://creativecommons.org/licenses/by/4.0/). 